\title{
Time in English Translations of Continental News
}

\author{
Sara Barker
}

News tells us many things. It tells us what has happened, when and where it happened, and who was involved. It might even try to tell us why particular things have happened. Understanding what news is considered important within a society, what news is allowed, and how that news is exchanged, gets us closer to understanding those societies, both contemporary and historical. Investigations into early modern news also underscore how connected early modern communities were. Complementing traditional oral exchanges and established manuscript networks, stories about events both significant and trivial were written up, printed, read and exchanged across Europe, with hundreds of stories travelling hundreds of miles, crossing territories and language barriers. That people were concerned about how events happening in the wider world would affect them is to be expected. Recent and ongoing research projects have tackled the idea of early modern exchange in various forms, and show that people were highly aware of the shifting nature of their world. ${ }^{1}$ More specifically, pamphlets from the sixteenth and early seventeenth centuries confirm the existence of transnational concerns, particularly about the spiritual fallout of the fragmentation of Christianity. By sharing details of unfolding events and providing a common narrative in which people across a wide geographical area could share, these works gave a sense of collective European identity at a time when earlier shared ideals based around the idea of common faith were disintegrating. Yet international stories were framed in ways that suggest a strong, if not paramount, prioritisation of local and national concerns alongside interest in the international, through the ways in which these narratives were presented to their reading public, such as title-page formatting and selective use of supportive

1 For example 'Sailing into Modernity: Comparative Perspectives on the Sixteenth and Seventeenth Century European Economic Transition', < humanities.exeter.ac.uk/history/ research/centres/maritime/research/modernity/> [14/2/14], based at the University of Exeter; the Universal Short Title Catalogue <www.ustc.ac.uk/> [15/2/14], based at the University of St Andrews; the Renaissance Cultural Crossroads Catalogue <www2.warwick.ac.uk/fac/arts/ren/ projects/culturalcrossroads/> [14/2/14], based at the University of Warwick; and of course, the network from which the present volume derives, the News Networks in Early Modern Europe network. <newscom.english.qmul.ac.uk/index.html $>[13 / 2 / 14]$.

(C) SARA BARKER, 2016 | DOI 10.1163/9789004277199_015

This is an open access chapter distributed under the terms of the Creative Commons Attribution-

Noncommercial-NoDerivatives 3.o Unported (CC-BY-NC-ND 3.o) License. 
reading apparatus, including prefaces, notes to the original text as well as interjections in it.

The practical challenges faced by print producers, and how these were presented to the reader, also need to be taken into account when considering the ideological imperatives behind information exchange in the early modern world. International exchange was crucial in early modern news printing, but it was logistically complex. Several elements combined to complicate early modern news exchange, some more intractable than others. English readers received news from all over Europe, at a time when travel was not always simple. It took eight to ten days for a rider to get from Lyon to Paris: the emerging postal services might be able to move a little more quickly, if not dramatically so. ${ }^{2}$ Services between Antwerp and Amsterdam might take three to nine days, depending on the weather, an ambiguity that only became more pronounced when longer distances were involved. Travel was expected to slow down during the winter months, with English postal rates being set at seven miles an hour in summer, but six miles an hour in winter, with any kind of notably bad weather significantly increasing those times. ${ }^{3}$ Once news had travelled, news producers needed to select and package suitable stories into a sellable product, using the methods discussed throughout this chapter. And of course official regulations about what could and could not be printed as news needed to be adhered to. These practical issues could be dealt with by experienced practitioners with relative ease. Other problems required more imaginative solutions.

The overriding feature of news, both early modern and contemporary, is that it relates to information about current events, events happening now or in the very recent past. News is also expected to be new, to bring in previously unknown details to the consumer. In this respect, it is widely understood that early modern printed news lagged behind its oral and manuscript counterparts in its ability to cover distances at a swift enough pace to remain competitive. Of course, printed news worked with oral and manuscript news and is an excellent example of how early modern print culture did not exist hermetically sealed off from other forms of cultural exchange. Nevertheless, there is evidence to suggest that the emergent appetite for news in its various forms went hand in hand with a growing awareness of events happening within a universal timeframe in which those concerned - the people reading the stories and the people they were reading about—were common participants, leading

2 Arlette Jouanna, La France du XVI e siècle, 2nd edn (Paris: Presses Universitaires de France, 1997), p. 11.

3 These rates seem to have proved to be somewhat ambitious. Henry Kamen, Early Modern European Society (London: Routledge, 200o), p. 4. 
to an increased awareness of 'contemporaneity' within early modern European society. ${ }^{4}$ It is of course useful to know how long it took for an event to become a printed news story, and how quickly news passed between different communities. Such instances as the rapidity with which provincial towns heard of the massacres in Paris in August 1572 or the three days it took Sir Robert Carey to ride the four hundred miles from London to Edinburgh to inform James vI of the death of Elizabeth I are more than interesting anecdotes in an age of rapid transit travel, as such information exchanges had wide-ranging political and social consequences. ${ }^{5}$ Comparing dates and working out rates of travel does not explain where news producers thought their product fitted in amongst the other kinds of news available to consumers, or how it was to remain distinctive yet indispensable to consumers, particularly in the pre-periodical era. If we are to understand the technicalities of early modern news production, we need to consider how duration and chronology were explained to readers, in order to understand how the barriers between news and history developed.

This chapter explores both the shared understandings and the cultural and functional differences that international news accentuated by examining one particular factor: the representation of time from the mid sixteenth century to the 1620 s in English occasional news pamphlets about events on the continent, primarily translations of pre-existing foreign pamphlets. ${ }^{6}$ Whilst time was a universal experience, how it was experienced was highly individual. Trying to capture time in a news pamphlet only served to demonstrate how much of European society was in a state of flux.

4 Brendan Dooley, ed., The Dissemination of News and the Emergence of Contemporaneity in Early Modern Europe (Farnham: Ashgate, 2010).

5 The evidence from the various letters sent by Charles IX to his provincial lieutenants shows the king reacting to news coming back him about actions taken in response to his previous letters, all over a matter of a few days. Genevans first heard about the massacre on the evening of 29 August, with the first refugees appearing soon after. Antoine de Chandieu, for example, reached Geneva on 5 September, having heard the news in Lyon, and travelling over the Alps, presumably taking precautions to avoid detection. Philip Benedict, 'The Saint Bartholomew's Day Massacre in the Provinces', Historical Journal, 21.2 (1978), pp. 205-25. Auguste Bernus, 'Le Ministre Antoine de Chandieu d'après son journal autographe (1534-1591)', Bulletin de la société d'histoire du Protestantisme Français, 38 (1888), pp. 393-5. On Sir Robert Carey, see Daniel Woolf, 'News, History and the Construction of the Present in Early Modern England, in The Politics of Information in Early Modern Europe, ed. Brendan Dooley and Sabrina A. Baron (London: Routledge, 2001), pp. 80-118, at 84-5.

6 The research discussed here is based on data gathered initially as part of the Renaissance Cultural Crossroads Project, which identified several hundred translations of news and current events related printing in early modern England. 


\section{Understanding Time in Early Modern Europe}

Early modern people were living in a clash of times. They enjoyed a complex inheritance which blended classical models, in which time was understood as cyclical, and traditional Christian conceptualisations, by which time was both identified with human history and limited by God's great acts on earthnotably the Creation, the Incarnation, and (finally) the Last Judgement — and with the infinite time connected to God's being, stretching beyond the End of Days into eternity. People were expected to shift between these two modes of thinking relatively seamlessly, as well as taking into account their own quotidian experiences. Further conceptual developments had emerged over the course of the medieval period. Where once Time had mainly been measured in terms of the dictates of the natural world - day turning to night, the changing seasons, the demands of the agricultural year-increasing emphasis was put upon time as a measurable commodity. ${ }^{7}$ This was borne out by the era's technical developments. Bells which had chimed the hours of prayer increasingly told listeners the timetables of work and trade, as well as reminding them of their religious obligations, with people became more accustomed to dividing up the day in terms of hours. ${ }^{8}$ These kinds of notations are visible in the various genres of news accounts available in the early modern period. Describing the bombardment of a church during Henri Iv's siege of Noyon, it was noted that the canon "played upon it from morning untill three of the clocke in the after noone". ${ }^{9}$ Reporting the taking of Steenwijk in 1592, clock time was used to note the siege's start, the duration of a bombardment "beginning at foure of the clocke in the morning and continuing till nine" and a night-time sortie launched against the besiegers. ${ }^{10}$ When the usurer George Rolet was eaten

7 Jacques Le Goff, Time, Work, and Culture in the Middle Ages, trans. Arthur Goldhammer (Chicago: University of Chicago Press, 1980), particularly 'Merchant's Time and Church's Time in the Middle Ages'. See also Craig Koslofsky, Evening's Empire: A History of the Night in Early Modern Europe (Cambridge: Cambridge University Press, 2011) and Anthony F. Aveni, Empires of Time: Calendars, Clocks and Cultures (London: I.B. Tauris, 1990). Robert Mandrou, Introduction à la France moderne (1500-1640): Essai de Psychologie historique (Paris: Albin Michel, 1961), pp. 95-8. Carlo M. Cipolla, Clocks and Culture 1300-1700, new edition with introduction by Anthony Grafton (London \& New York: Norton, 2003). David S. Landes, Revolution in Time: Clocks and the Making of the Modern World (Cambridge, MA \& London: Harvard University Press, 1983).

9 A True Declaration of the Honorable Victorie obtained by the French King in winning of Noyan (London, 1591), sig. Bir-v, USTC 511743.

10 A True declaration of the straight siedge laide to the Cytty of Steenwich (London, 1592), sigs. A2v, Bir, Biv, USTC 512256. 
alive by rats near Aix-en-Provence in 1606 , it was noted that "he died the second of August, in the yeare of our Lord 1606, about foure of the clocke in the afternoon".11 One account of the assassination of Henri IV told readers that Henri set out on his fateful journey at "about three of the clocke in the after noone". ${ }^{2}$ In The True Description of the Execution of Justice, done in the Gravenhage, by the Counsell of the Generall States holden for the same purpose, upon Sir John van Olden Barnavelt, not only did the title page carry the information that the execution was carried out "at ten of the Clocke in the morning", but the account itself noted that Van Oldenbarnevelt delivered a scaffold-side speech to at least two thousand people "after hee had prayed upon his knees for the space of one quarter of an houre". ${ }^{13}$ In including these kinds of details, news writers followed precedents laid down by medieval chroniclers, who began to note the hours of events in their narratives around the time that public clocks began to be seen in European cities. Important happenings such as births and deaths of notable people, natural phenomena, battles and political events were all increasingly noted in chronicles in terms of hours of the day by the fourteenth century, a fashion that continued into the printed news era. ${ }^{14}$

The early modern era had to deal with the change from the Julian to the Gregorian calendar, correcting a drift from 'real time'. The original roman computations had rendered the year eleven minutes and fourteen seconds too long, which had a significant impact of the celebration of Easter. Several attempts to correct the discrepancy failed, before Pope Gregory XIII put in motion a conclusive plan for calendar reform in $1582 .{ }^{15}$ This was implemented in different countries at different times, guided largely by local religious sensibilities: Italy, Spain, France and Portugal made the switch in 1582, with other territories following suit throughout the 1580 s (Prussia and Flanders in 1583, Poland in 1586 and Hungary in 1587). Protestant territories did not change their calendars until much later, often not until the eighteenth century, so for

11 A Spectacle for Usurers (London, 1606), sig. A4r.

12 A Lamentable Discourse, upon The paricide and bloudy assassination: committed on the Person of Henry the Fourth (offamous memory) King of France and Navarre (London, 1610), sig. A3v.

13 The True Description of the Execution of Justice, Done in the Gravenhage, by the Counsell of the Generall States holden for the same purpose, upon SirJohn van Olden Barnavelt (London, 1619), sig. A2r.

14 Gerhard Dohrn-van Rossum, History of the Hour: Clocks and Modern Temporal Orders (Chicago: University of Chicago Press, 1996), p. 220.

15 Jennifer Powell McNutt, 'Hesitant Steps: Acceptance of the Gregorian Calendar in Eighteenth Century Geneva', Church History, 75.3 (2006), pp. 544-64. 
over a century, people were living not simply in different time zones, but at different points in Christian history. ${ }^{16}$ The switch was not simple. There were debates over the mathematical reasoning behind the calendar change, and discussions over the Catholic Church's authority and motivation for leading the change. Several commentators even argued that given the imminence of the Apocalypse, such modifications were really little more than windowdressing. Where Catholics and Protestants lived in close proximity, as they did in parts of Germany and Austria, the calendar change was yet another example of how Protestants and Catholics lived their lives according to different rules and priorities, and, as it turned out, on different days. All levels of daily life became highly confessionalised, from whether or not one observed dietary regulation on Fridays, to when Friday really was, to when Christmas actually fell. ${ }^{17}$ Such time differences might even have been a factor in winning or losing on the battlefield. ${ }^{18}$ The calendar change also caused confusion for people corresponding with, and reading news about, people operating in different 'time zones'. Generations of students and scholars have been faced by the English reply to a continental letter seemingly responding before the initial letter could possibly have been delivered. Further dating confusion is caused by the tradition in some parts of Europe of dating the year from Easter, a practice that began to shift in the sixteenth century, while the English New Year fell on Lady Day (25 March).${ }^{19}$ What for the modern reader is a potential pitfall carried

16 A helpful guide to the various calendar changes can be found at: <www.nottingham .ac.uk/ManuscriptsandSpecialCollections/researchguidance/datingdocuments/julian gregorian.aspx $>[9 / 04 / 15]$.

17 Rona Johnston Gordon, 'Controlling Time in the Hapsburg Lands: The Introduction of the Gregorian Calendar in Austria below the Enns', Austrian History Yearbook, 40 (2009), pp. $28-36$.

18 Hiram Morgan has suggested that the outcome of the Battle of Kinsale at the end of the Nine Years War was in fact down to the fact that the opposing armies were, to all intents and purposes, fighting on different days. The Spanish and Irish contingents were fighting in the new year, on 3 January 1602 , after the celebrations for Christmas and New Year. The opposing English, however, were fighting on 24 December of the previous year, and as such were anticipating their Christmas dinner, rather than experiencing a January slump. Hiram Morgan, 'The Pope's new invention: the introduction of the Gregorian calendar in Ireland, $1583^{-1782}$ ', unpublished paper cited by Brendan Dooley, 'Introduction', in Dissemination of News, pp. 1-19, at 6.

19 For example, in France the year began on Easter Sunday. Events happening in January 1563 would still carry the year 1562 until Easter. 1 January became the starting point of the year in 1564 . The ensuing complications are frequently addressed by historians in the preliminary materials to monographs. 
serious ideological weight at the time of composition, something of which news producers were well aware. ${ }^{20}$

\section{Representing Time in News}

Readers' chronological impressions of the news were formed from the first moments of their engagement with a pamphlet. Chronological pointers about the content and the production of the pamphlet were customarily addressed on the title page, directly in that they often featured dates, indirectly through other qualifiers. The complexity of title page design suggests that producers were highly aware of the power that these spaces had over potential purchasers and readers. Whilst this consideration was important for all kinds of books, in the context of news production, the delicate balance needed to achieve a desirable product is even more evident. The inclusion of the year of publication on the title page, typically included alongside the details of the printer and their location, automatically gave readers a temporal grounding. Whilst the inclusion of these details undoubtedly owed much to stylistic convention, in the context of international news publication, the relatively prominent position of the year as the final detail on the title page - often the only numerical element in this highly visible section and conventionally found at the end of a line-served as an extra clarification that the news was not outdated. So established as to be almost ubiquitous, the effectiveness of this temporal signifier becomes readily apparent when the numbers appear not to add up, as in Newes out of Germanie, printed in London in 1612, but noted on the title page as having its origins in a French pamphlet of the previous year. ${ }^{21}$ In the case of Good Newes from Florence: Of a Famous Victorie Obtained against the Turkes in May last 1613. by both Sea and Land, additional information on the title page suggests why that version took so long to be produced, as it had been 'Translated faithfully into English out of the French copie, printed with priviledge at Paris and taken out of the Italian discourse printed at Florence. ${ }^{22}$

20 Changing the calendar was also of course an act of control over multiple facets of people's lives, something which has been explored in the modern colonial context. Giordano Nanni, The Colonisation of Time: Ritual, Routine and Resistance in the British Empire (Manchester: Manchester University Press, 2012).

21 Newes out of Germanie. Or The surprizing of the Citie of Prage by the Arch-duke Leopold, and what there passed in the moneths of February and March last (London, 1612).

22 Good Newes from Florence: Of a Famous Victorie Obtained against the Turkes in May last 1613. by both Sea and Land (London, 1614). 
That such discrepancies are so distinct results from another commonplace of news printing, the inclusion of dating materials within the extended title. Dates of some form routinely appear within the titles of news works, either giving a clear reference to the date of one specific event, placing an event within a wider ongoing situation in which the occurrence under discussion is only one element, or by introducing multiple events together as part of an ongoing narrative. The vast majority of these indicators replicate the date given with the imprint. The frequency with which such details are clarified, by referring to "May last 1613" and underscoring that particular story's long journey to the present copy in the example cited above, or by reminding the reader that these events had occurred in "this present year" or the like, suggests that this was more than a simple reportage of information..$^{23}$ Titles were deliberately constructed to make readers think about exactly when events had happened or to make them recognise that they were still happening. Partly this can be explained by the bookseller's wish to reiterate how current the news was. In the account of the Archbishop of Cologne's proclamation and edict, the date for the initial event, the proclamation, is given as 1583 , halfway down the title page, in a separate paragraph, and clarified within the pamphlet as happening on 16 January. This is swiftly followed in the next paragraph by a reference to the original pamphlet from which this translation was made; a version printed in Antwerp, with the year repeated, 1583 . Finally, the reader is given a date for the printing of the English translation, 18 March 1583 . The sense that this is up to date is clear. The timing of the event was made to work with the usual apparatus of the pamphlet's publication in order to convey a sense of the present. ${ }^{24}$

Unsurprisingly, the most common form of time notation within titles was in the form of a reference to the date of the event being reported. At the most basic level, this could simply record the year of the event in question, as in Letters sent from Venice. ANNO. 1571, which gives an account of the battle of Lepanto or in A Discourse of that which happened in the battell fought betweene the two Navies of Spaine and Portugall, at the Ilands of the Azores. Anno Dom. 1582., which outlined the events of the Battle of Ponta Delgarda during the Portuguese succession crisis of the early 1580 s. $^{25}$ Accounts of

23 As in Newes from France. Or A relation of a marvellous and fearfull accident of a disaster, which happened at Paris the seventh day of March, this present yeare of 16r8, where by meanes of a terrible fire, all the Pallace was burnt and consumed (London, 1618).

24 The Proclamation and Edict of the Archbyshop, and Prince Elector of Culleyn (London, 1583), ustc 509756.

25 Letters sent from Venice. Anno. 1571 (London, 1571?), USTC 507369; A Discourse of that which happened in the battell fought betweene the two Navies of Spaine and Portugall, at the Ilands of the Azores. Anno Dom. 1582 (London, 1583?), UstC 509676. 
military encounters, a news mainstay, were typically introduced with a clear indication of the date:

A True Report of the yeelding up of the Cittie of Antwarpe, unto the Prince of Parma, which was on the seaventeenth day of August last past. $1585 .{ }^{26}$

A Briefe discourse of the merveylous victorie gotten by the King of Navarre, against those of the holy League, on the twentieth of October. $1587 \cdot{ }^{27}$

The Overthrow of the most part of the Prince of Parma his forces, both horse and foote. Performed on the twelfth and fifteenth of July last, by the Grave Maurice his Excellencie, Generall of the Armies in the Lowe Countries. ${ }^{28}$

The honorable Victorie obtained by Grave Maurice his Excellencie, against the Cittie of Rhyne-berg, the 20. of August. 1597. ${ }^{29}$

In other examples, a date is included as part of the general information given on the title page, but not as part of the initial title. The reasons for deferring the date inclusion tend to relate to practical issues about constructing the pamphlet, rather than any ideological issues. Thus, on the title page of the clearly detail-focused A Large and True Discourse, wherein in set foorth all the circumstances, in what manner all the sixe great Gallies (sent out of Spayne into the Low Countries) are destroyed, forced, and runne on ground, how they were called, what Captaines and Gouernours commaunded, the number of Souldiers, Ordnance and Slaves: what ships of warre of ours did stemme and sailed over them, and also what number of their people were saved, it is only in the next paragraph that a date is given, and that relates to the production of the account, rather than the events being discussed: "All written aboord the ship of Captaine Gerrit Evertson, in the presence of Captaine Jacob Micheelson, Captaine Corneles Veytson, Captaine Cleinsorghe and others, the seventh day of October 1602". 30

26 A True Report of the yeelding up of the Cittie of Antwarpe, unto the Prince of Parma, which was on the seaventeenth day of August last past. 1585 (Amsterdam, [1585?]), USTC 426484.

27 A Briefe discourse of the merveylous victorie gotten by the King of Navarre, against those of the holy League, on the twentieth of October. 1587 (London, 1587), USTC 510795.

28 The Ouerthrow of the most part of the Prince of Parma his forces, both horse and foote. Performed on the twelfth and fifteenth of July last, by the Grave Maurice his Excellencie, Generall of the Armies in the Lowe Countries (London, 1591), USTC 511746.

29 The honorable Victorie obtained by Grave Maurice his Excellencie, against the Cittie of Rhyne-berg, the 20. of August. 1597 (London, 1597), USTC 513431.

$30 \quad$ A Large and True Discourse, wherein in set foorth all the circumstances, in what manner all the sixe great Gallies (sent out of Spayne into the Low Countries) are destroyed, forced, and runne on ground (London, [1602]). 
In A Most Excellent exploit perfourmed by Monsieur de Diguieres, the French Kinges Lieutenant, upon the Popes Armie which was under the conduct of Earle Hercules the Popes Nephew, the title page's chronological explanations match the format of the text. The reader is told that the "exploit" in questionLesdiguière's encounter with Ercole Sfondrati, Duke of Montemarciano near Grenoble in September 1591-will be accompanied with "A Discourse of the overthrow of the Duke of Savoyes army defeated by the Lord de Diguieres, in the plaine of Pont-Charra, near to Castle Bayard, in the vale of Guesiuodan the eighteenth of September 1591". The clash between Lesdiguière and Montemarciano is dealt with swiftly, before a second section addresses the actions of the King's own army, "A discovery uppon such accidents as have happened in the French King his army, sithence the first day of October, untill the fifte of the same moneth" (sigs. A2v-4v). The account of Lesdiguière's victory over the Duke of Savoy has its own title page at Bir, which reiterates the dating information given on Arr. ${ }^{31}$ Newes from France, a letter-based pamphlet describing the same events, is even more direct in its approach:

Newes from France. Where Monsieur de Signiers in the Kings behalfe, most bravely discomfited the Armie of the King of Spaine, and the Pope, consisting of ten thousand strong, being Neapolitans, Spaniards, Savoians and Burgonians. With the taking of fifteene Ensignes, the number that were slaine, and how many were taken prisoners, which Armie was sent to surprize Languedock and Grenoble. This happened the 18. of September. $1591 .^{32}$

These examples suggest that if a date was not immediately forthcoming for the title of this kind of pamphlet, book producers would happily appropriate dating apparatus from other parts of the work.

Of course, determining the date of a given event could be quite tricky, given the continuing ambiguities over the start of the year and the calendar. In fact, given the drama of the calendar change, it is perhaps surprising pamphlet producers managed to deal with this relatively painlessly. This was mainly a concern when news crossed between cultures operating in the different calendars-after 1583, news from France and the Catholic Low Countries in England would be

31 AMost Excellent exploit perfourmed by Monsieur de Diguieres, the French Kinges Lieutenant, upon the Popes Armie which was under the conduct of Earle Hercules the Popes Nephew (London, 1591), USTC 511715. See also Jean-Denis Long, La Reforme et les guerres de religion en Dauphiné de 1560 à l'edit de Nantes (Geneva: Slatkine, 1970).

Newes from France (London, [1591]), USTC 511740. 
coming from the future, so to speak. The simplest way of addressing the issue was to note that the date of the original event or work was being given in the new style, using the term Stilo Nuovo or an equivalent:

A Short and True Discourse for satisfying all those who not knowing the truth, speake indiscreetly of hir most excellent Majestie, of the Lord Willughby Governour of hir Majesties succours in the united Provinces of the Low countries, and of all the English nation: by occasion of a strange placcat [sic] of the 17. of April 1589. the new stile, put foorth by certaine persons (as is said) under the name of the Generall States of those united Provinces. ${ }^{33}$

The French Kings declaration against the Dukes of Vendosme and Mayenne, The Marschall of Bouillon, the Marques of Coeurre, the President le Jay, and all who assist them. Verified in the Court of Parlement the 13. of February. 1617. Stilo Novo. ${ }^{34}$

The True description of the Execution of Justice, done in the Gravenhage, by the Counsell of the Generall States holden for the same purpose, upon Sir John van Olden Barnavelt. Against whom the said states purposely thereunto appointed, did worthily pronounce sentence of death according to his deserts: which was executed upon the third day of May, 1619. Stilo Novo. at ten of the Clocke in the morning ... ${ }^{35}$

A rather more loaded alternative was to underscore the difference by drawing attention to the reason why there were different calendars in operation, or at least to highlight the authority behind the recent shift:

A letter sent by the French King unto Monsieur de la Verune Liefetenant for his Majestie at Caen in Normandie, concerning the most happy victory which he obtained against the Leaguers and Rebels in his Kingdome, upon the 14. daie of March last past, according to the Romane computation. ${ }^{36}$

33 A Short and True Discourse for satisfying all those who not knowing the truth, speake indiscreetly of hir most excellent Majestie ([London], 1589), ustc 511366.

34 The French Kings declaration against the Dukes of Vendosme and Mayenne, The Marschall of Bouillon, the Marques of Coeurre, the President le Jay, and all who assist them (London, 1617).

35 The True Description of the Execution of Justice.

$36 \quad$ A letter sent by the French King unto Monsieur de la Verune Liefetenant for his Majestie at Caen in Normandie (London, 1590), UstC 511436. 
The True Coppie of a Letter, written from the Leager by Arnham, the 27. day of July, according to the Computation of the Church of Rome. ${ }^{37}$

The True Coppy of a certaine Letter written from Sluce the 12. of June 1606. (according to theyr Computation) ... ${ }^{38}$

This last case is relatively ambiguous, simply acknowledging the differences, rather than attributing responsibility to the Catholic Church, as the previous examples do. Some pamphlets demonstrate a more direct recognition of the difference according to country. The following examples from 1592, a particularly fruitful year for English translations and accounts of French news, show the subtle differences:

A Discourse of that which is past, since the kings departure from Gouy, to pursue the prince of Parma: even til the first of May. 1592. The last letters therof came on the fourth of the same month according to the English computation. ${ }^{39}$

A Journall, wherein is truely sette downe from day to day, what was doone, and worthy of noting in both the Armies, from the last coming of the D. of Parma into Fraunce, untill the eighteenth of May 1592, according to the French computation. ${ }^{40}$

These pamphlets essentially mirror each other, with the Journall's scope noted as being up to 18 May "according to the French computation", and the Discourse giving the date of the last letters "according to the English computation". These are both from the presses of John Wolfe, an experienced printer of this kind of material, and given that these two pamphlets would have been produced very close together, the distinction is all the more intriguing. The reason for the differentiation is not immediately clear, although the Journall announced itself as a translation on the title page, whereas the Discourse did not. Wolfe's customers presumably expected translated materials to come with their dates 'translated' as well, whereas English works about France could use English dating, but were expected to clarify the discrepancies. Nonetheless,

37 The True Coppie of a Letter, written from the Leager by Arnham, the 27. day of July (London, 1591), USTC 511735 .

38 The True Coppy of a certaine Letter written from Sluce the 12. of June 1606 (London, 1606).

39 A Discourse of that which is past, since the kings departure from Gouy, to pursue the prince of Parma: even til the first of May. 1592 (London, 1592), USTC 512027.

40 A Journall, wherein is truely sette downe from day to day, what was doone, and worthy of noting in both the Armies (London, 1592), USTC 512032. 
date differentiation was clearly needed, and catered to. The distinction could also be made within the text. The Overthrow of the most part of the Prince of Parma his forces, describes one of the Prince's attacks happening "upon Monday being the 12 day of July last past after our English computation". ${ }^{41}$ The exact differences might also be laid out, as when announcing Ambrogio Spinola's arrival at Aachen in 1614, noted as being on "twentyth of August last, in this present yere, 1614. according to the Romain computation, and the fifteenth of August in our account". 42

Attributing a date to the events being discussed was therefore an integral expectation of such publications. It could testify to the pamphlet's relevance, as well as highlighting the factual content contained within its pages. However, immediacy was but one factor in understanding a given event's relevance to an audience. Longer divisions of time are also referred to in news pamphlets. There is much evidence to suggest that readers were understood to see individual events as bring part of an ongoing story, and other instances of title page dating were designed to position the news within this broader history. In The Kinges Edict or decree upon the pacification of the troubles of his Realme of 1568 , the edict of the title is noted as "conteyning also the confirmation of another like Edict", that of Amboise which had ended the first active phase of the French religious wars in $1563 .{ }^{43}$ The brief aside to the former date quickly and neatly establishes this current edict's context, before the reader is pulled back to the present with the advertisement of extra material in the pamphlet, the requests made by the protestants, and reminded that this has been "nowe translated" out of the French. More typically, the title made reference to a range of dates or indicated an ongoing situation, either one that had passed or one that was still ongoing. In A True Report of all the proceedings of Grave Mauris before the Towne of Bercke, the reader is given a time range for the siege, from 12 June 1601 to the town's surrender on 30 July, and a hint of subsequent actions, the conditions agreed upon by the governor and Maurice. Pinning the ongoing situation to one or more stated dates was a particularly common approach:

\footnotetext{
41 The Overthrow of the most part of the Prince of Parma his forces, sig. A4v.

42 The Wars in Germany, With the taking of the severall townes by the Marquesse Spynola (London, 1614), sig. A3v.

43 The Kinges Edict or decree upon the pacification of the troubles of his Realme ([London], 1568), USTC 506783. The Edict of Amboise is dated to "the xix. day of March 1562" because of the change in when the year was understood to start. The text of the 1563 edict is included in the edition.
} 
A letter written by the King of Navarr, to the three estates of Fraunce: Containing a most lively description of the discommodities and dangers of civill warre: and a very forcible perswasion to obedience, unitie, and peace. Together with a breefe declaration upon the matters happened in Fraunce sithence the 23. day of December, $1588 .{ }^{44}$

A Journall, wherein is truely sette downe from day to day, what was doone, and worthy of noting in both the Armies, from the last coming of the D. of Parma into Fraunce, untill the eighteenth of May 1592, according to the French computation. ${ }^{45}$

A True Discourse of the most happy victories obtayned by the French King, against the Rebels and enemies of his Majesty. With a particular declaration of all that hath beene done betweene the two Armies, during the monthes of September and October, and part of November. $1589 .{ }^{46}$

A Dialogue and complaint made upon the siedge of Oastend ... Also a true discourse of that which is hapned in the same towne of Oastend, from the fourth day of the moneth of February $1602 .{ }^{47}$

A Wonderfull and most Lamentable Declaration of the great hurt done, and mighty losse sustained by Fire that hapned: and mighty stormes of Winde, Thunder, Lightning, Haile, and Raine, with Inundations of Water, that fell in the Towne of Errford and Weinmar ... In the Month of May, but much more in the month of June last past, Anno, $1613 .{ }^{48}$

Other stories might be a little less definite in terms of precision dating, but they still managed to strike a balance between event and ongoing situation:

A Recitall of that which hath happened in the Kings Armie, since the taking of the Suburbes of Paris, untill the taking of the Towne of Humflet. ${ }^{49}$

44 A letter written by the King of Navarr, to the three estates of Fraunce (London, 1589), USTC 511307 .

45 A Journall, wherein is truely sette downe from day to day, what was doone, and worthy of noting in both the Armies.

46 A True Discourse of the most happy victories obtayned by the French King, against the Rebels and enemies of his Majesty (London, 1589), UstC 511370.

47 A Dialogue and complaint made upon the siedge of Oastend, made by the King of Spaine, the Archduke, the Infanta, the Pope, the Prince Morrice, and the eldest sonne of Savoye (London, 1602).

48 A Wonderfull and most Lamentable Declaration of the great hurt done, and mighty losse sustained by Fire that hapned (London, 1613).

49 A Recitall of that which hath happened in the Kings Armie, since the taking of the Suburbes of Paris, untill the taking of the Towne of Humflet (London, 1590), USTC 511431. 
Newes out of Cleave-land: Being the true relation of the taking in of the towne and castle of Gulicke in Germanie, with the articles of peace there concluded and agreed upon. As also the services and fights, performed while the siege lasted. ${ }^{50}$

A True Recital of those things that have been done in the Court of Fraunce, since the death of the Marshall d'Ancre, untill the departure of the Queene mother from the King. ${ }^{51}$

The title page typically displays time in terms of a single dated event, or episodically, as a series of events, possibly ongoing. Many of the pamphlets include postscripts or hastily added-in material from letters just received. A Discourse of that which is past, since the kings departure from Gouy, to pursue the prince of Parma: even til the first of May. 1592 gives a remarkably full title-page description of this process: "The last letters thereof came on the fourth of the same month according to the English computation. with new additions by later letters". ${ }^{52}$ Additional material could arrive after the first version of a pamphlet had been printed. The Oppugnation, and fierce siege of Ostend was updated to become Newes from Ostend, of The Oppugnation, and fierce siege of Ostend, noting that it was "Now newly imprinted; whereunto are added such other Newes and Accidents as have lately hapned at Ostend, as we have bin certainely informed".53 This "other Newes" is a side and a half of details gathered from various sources arriving in London. These are dated in relation to the writing of the postscript. Information from the Antwerp post came "three dayes past (namely the thirteenth day of this moneth of August)", with more updates arriving by sea "on friday last being the fourteenth day of this present moneth of August". ${ }^{54}$ As well as stressing how up to date the information was, this

$5^{\circ} \quad$ Newes out of Cleave-land: Being the true relation of the taking in of the towne and castle of Gulicke in Germanie, with the articles of peace there concluded and agreed upon (London, 1611).

51 A True Recital of those things that have been done in the Court of Fraunce, since the death of the Marshall d'Ancre, untill the departure of the Queene mother from the King (London, 1617).

52 A Discourse of that which is past, since the kings departure from Gouy (London, 1592), USTC 517259 .

53 The Oppugnation, and fierce siege of Ostend (London, 1601) and Newes from Ostend, of The Oppugnation, and fierce siege of Ostend (London, 1601). Interestingly, the earlier version states on the title page and at sig. A3r that the Duke of Osuna came before Ostend on 5 June, whereas the later version makes this 5 July on the title page and sig. Alv, with both giving the date as "fifth day of June (after the new stile)" within the text, on sigs. Bir and A $3 v$ respectively. The reason for this discrepancy is unclear.

Newes from Ostend, sig. B4r. 
approach underscores how seemingly straightforward translations were in fact complex hybrids of pamphlet, oral rumour and material from letters, where the reader was made to feel as if they were learning the latest along with the book producer.

Beyond the immediacy of the title page, more complex evidence of people's understandings and concerns about time emerges. Paratexts discuss time largely in one of two ways: the paratext's author, usually the translator, discusses the time line of the production of the work, or they situate the pamphlet subject matter as part of a historical narrative. True Newes of a notable victorie obtayned against the Turkes noted that "a fewe yeeres past" the Turks had taken Raab and that this loss was "well knowne unto many", before outlining how the city had been retaken by Adolf von Schwarzenberg. ${ }^{55}$ Pamphlets recounting the execution of François Ravaillac, Henri IV's assassin, prefaced the account by acknowledging that France had been left in a state of turmoil since the murder, thereby justifying the publication of information about Ravaillac's death, implying a sense of overall resolution. ${ }^{56}$ The aforementioned accounts of the siege of Ostend started with a full description of the town, its port and its role in the previous conflict, before coming on to the details of the current situation of the town. ${ }^{57}$ Other accounts would open almost in media res, or assuming prior knowledge of the situation. A Discourse of that which is past, since the kings departure from Gouy, to pursue the prince of Parma apparently picks up where a previous pamphlet left off:

The King continuing hys enterprise to fight with the duke of Parma, and of the Mayne, and to give them battell according to the last order of his departure from Gouy: to the end nothing were forgotten that might draw and force the enemy to come to a battel: the king without any sojourning, came in great hast to lodge in Netiville a league, \& one halfe distant from Ivetot, where part of the forces of the said dukes was quartered, \& intrenched. ${ }^{58}$

Similarly, Articles of Agreement, Concerning the Cessation of War, describing the negotiation of the 1607 ceasefire between the United Provinces and the

55 Raab is Győr in northwest Hungary. True Newes Of a notable victorie obtayned against the Turkes (London, 1598), sig. A3r, USTC 513804.

$5_{6}$ See for example The Terrible and deserved death of Francis Ravilliack (London, 1610).

57 The Oppugnation, and fierce siege of Ostend and Newes from Ostend, of The Oppugnation, and fierce siege of Ostend.

$5^{8}$ A Discourse of that which is past, since the kings departure from Gouy, sig. A2r. 
Habsburgs, opens "You have heard howe a Fryar, the Confessor to the Infanta, hath brought about a Cessation of Armes for 8. Moneths". ${ }^{59}$ The 'you' is somewhat ambiguous. It could be a general reference to the imagined reader. But the translator W.BB notes (on A3r) that the accounts had "lately come to my handes from a worthy friend out of Holland", so it could also refer to a direct translation of personal correspondence, a well-established approach in early news. ${ }^{60}$ Reproducing letters to convey news provided an immediate temporal framework within which the information being conveyed became tied to personal experiences. This became even more pronounced when multiple letters or letter exchanges were included in the same pamphlet. In Articles of Agreement, this is clearly one single episode in an ongoing narrative with which the writer either knows or assumes the reader is already familiar. The news did not and should not stand alone.

As noted earlier, Christian worldviews blended Time and History. The individual events described in pamphlets were part of an ongoing story with a known end-the Day of Judgement. In the pamphlet form, where there was room for editorialising and framing, such stories bridged the gap between the quotidian and the eternal. In A true rehersall of the Honorable \& Tryumphant Victory: which the defenders of the Trueth have had againste the tyranical and bloodthirsty heape of ye Albanists, the direct title is backed up by the text:

\begin{abstract}
Althoughe all thynges (welbeloved and christian Reader) whiche by the grace of God, are come to passe within the renowmed Citie of Harlam in Holand, are worthye, not by peeces, but from the beginning unto the end to bee rehearsed, and set before the eyes of all men: that the wonderful and worthy works of God thereby may bee knowen, and his name for ever magnified \& praised. $^{61}$
\end{abstract}

All forms of news contributed to this Christian worldview, with some particularly noteworthy for their "heavy-handed providentialism". ${ }^{62}$ Readers were left in no doubt as to how they were meant to interpret individual events as part of a longer pattern, that these happenings were not random but rather

\footnotetext{
59 Articles of Agreement, Concerning the Cessation of War (London, 1607), sig. A4r.

6o As outlined by David Randall in Credibility in Elizabethan and Early Stuart Military News (London: Pickering and Chatto, 2008).

61 A true rehersall of the Honorable \& Tryumphant Victory ([London], 1573), sig. A3r, UstC 507595 .

62 Alexandra Walsham, Providence in Early Modern England (Oxford: Oxford University Press, 1999), p. 118.
} 
God-given indications that the inhabitants of early modern Europe stood at a dangerous point in time. The letter to the reader in a monstrous birth case states this clearly:

Dearly beloved Bretheran like as daily wee see the wunderous woorks of GOD, to advertise us to the amendment of our sinful wicked \& detestable lives, before hee dooth plague us, like as alwaise hee is good and merciful and doth not punish us according unto our deserts, but sendeth us first Signes and tokens to admonish us of his ire ... but wee dayly neglecting and not regarding the same.... Wherefore wee have to give the greater account of the time which wee have spent, when we shall come and appear before the Judgement seat of GOD. ${ }^{63}$

This easy switching between the quotidian experience as imagined by the writer and the eternal experience of the day of judgement is seen elsewhere. The unambiguously titled Strange Newes of 1606, recounting events of the previous year in Carlstadt, moves seamlessly between a practical discussion outlining the processes by which the translation was made and an intellectual exploration of the implications of these events on the wider age. ${ }^{64}$ Unsurprisingly, natural disasters were frequently explained in terms of punishment for sin, with evidence from overseas being brought into play alongside homegrown evidence. An account of strange happenings near Frankfurt in 1606 reminded readers that "It is not longe since hee afflicted us here in England. First, with pestilence and mortalitie, and now last by death and famine", lamenting the continually high levels of sin within England, before outlining the events in Germany. ${ }^{65}$ Newes from Italie reminded readers of events in France and Spain that should have been taken seriously, before turning to the account of the landslide in Piuro that took two thousand lives. ${ }^{66}$ One of the previous events mentioned was a fire which engulfed much of the Palais de Justice in Paris in March 1618, described as "descended from Heaven, about midnight in the forme and fashion of a terrible great flaming starre", demonstrating God's anger. The same pamphlet also noted that "God hath preserved the Chappell called the Holy shewing to his people that he desires to be honored

63 An example of Gods judgement shew [n] upon two children borne in high Dutch la $[n d]$ in the Citie of Lutssolof (London, 1582), sig. A3r, USTC 509603.

64 Strange Newes (London, 1606).

65 A most straunge and wounderfull accident, happened at Weersburch by Franckford (London, 160o), A3v, USTC 517589 .

66 Newes from Italie (London, 1619). 
and glorified". ${ }^{67}$ Individual events were part of a wider European pattern, one in which fear of the individual events needed to be considered alongside longterm recognition of God's plans for the world. By bringing English readers closer to the continent, news pamphlets also connected the individually noteworthy moments of peoples' lives with the ultimate story, that of Christian Salvation. However, these tales tend to end rather ambiguously, as they depend upon the reader understanding the message and making sure that henceforth their behaviour will be beyond reproach. Lacking the evidence that this will happen, the stories fail to achieve final resolution and remain dangerously ambiguous.

In a similar vein, the significance of when events happened was never overlooked. This could be relatively prosaic, as when a pamphlet noted that the Elector Palatine was chosen as king by the States of Bohemia in a public assembly on 16 August, which happened to be his birthday. ${ }^{68}$ Sometimes the timings of events within the story could make the events all the more impressive. Military accounts structured themselves in terms of the actions of the opposing sides - one commander launches an attack, the other side responds and so on-resulting in a broadly naturalistic rhythm. Other story types could be more dramatic. In an account of three monsters born in Namen in December 1608 , readers learned that "at the same instant time as this poor woman was delivered", the wicked sister whose deeds had provoked the crisis was killed in a different part of the town when the ground swallowed her up as she fled her house that had been struck by lightning. ${ }^{69}$ The title page image, showing the woman fleeing the burning house in the middle of the page, and the three monsters in a row at the bottom, helps convey the simultaneous nature of the action. In the chilling story of George Rolet, the power of the story hangs on two dramatic exchanges, where the immediacy of the events is crucial. Rolet has just announced that he would rather be eaten by rats than sell his corn for less than five schillings a bushel, when "therewithall, at the same instant", a poor woman to whom he had lent money appears. When she pays back her debt, there is a disagreement over how many rings Rolet took from her as surety for the loan, and he again makes a sweeping statement about being eaten by rats if he is not telling the truth, only this time "She had scarce

\footnotetext{
$67 \quad$ Newes from Fraunce (London, 1618), sigs. A3v and A4v.

68 The Reasons which compelled the States of Bohemia to reject the Archiduke Ferdinand \&c. \& inforced them to elect a new King (Dort, [1619]).

69 A True Relation of the birth of three Monsters in the City of Namen in Flanders (London, 1609).
} 
made an ende of her prayer, but immediatly there came (a wonderfull thing to tel) an innumerable sort of Rats, which set upon this Usurer".70 Divine retribution should be expected to be immediate, it would seem.

Frequently the passage of time was integral to the story itself. In the case of Peter Stumpp, the Werewolf of Bedburg, the fact that his crimes took place over the course of 25 years was central to the story. Not only was the duration noted prominently on the title page, but the author makes several references within the text to Stumpp's crimes being horrific in themselves but also in their duration, discussing "the cruelties committed and the long time therin continued" and that the pamphlet outlines the "life and death and most bloody practices" of a man who "was a murderer from the beginning", noting in particular the misdeeds of his adolescence. ${ }^{71}$ The pamphlet telling the story of the serial killer Christman Genipperteinga announced on the title page that he held a woman captive for seven years in a cave, fathering multiple children with her, in addition to noting his 96o-plus victims..$^{72}$ The story of Katerin Cooper who did not eat, drink or sleep for seven years not only announces the duration of her fast on the title page, but goes on to break down the period into smaller chunks as part of the investigation. ${ }^{73}$ In the story of Eve Flingen, another fasting 'miracle maiden', the process by which she cut food out of her life is carefully measured out in terms of days and years. ${ }^{74}$ In all of these stories, the extended duration of the events under discussion is integral to understanding their intended appeal to the reading public.

$70 \quad$ A Spectacle for Usurers, sigs. A3r, A4r.

71 A true Discourse. Declaring the damnable life and death of one Stubbe Peeter, a most wicked sorcerer, who in the likenes of a Woolfe, committed many murders, continuing this divelish practise 25. yeeres, killing and devouring Men, Woomen, and Children (London, 1590), sigs. A2r-3r, UsTC 511409 .

$72 \quad$ Newes out of Germanie. A most wonderfull and true discouse of a cruell murderer, who had kylled in his life tyme, nine hundred, threescore and odde persons among which six of them were his owne children, begotten on a young woman which he forceablie kept in a Cave seven yeeres, with the manner how he was taken, and the aboundaunce of wealth that was found in the said Cave (London, 1584), USTC 510114.

73 A notable and prodigious Historie of a Mayden, who for sundry yeeres neither eateth, drinketh, nor sleepeth, neyther avoydeth any excrements, and yet liveth (London, 1589), USTC 511154 .

74 The Protestants and Jesuites up in Armes in Gulicke-land (London, 1611). See also Nancy A. Gutierrez, 'Shall She Famish Then?': Female Food Refusal in Early Modern England (Aldershot: Ashgate, 2003), pp. 79-102. 


\section{Conclusion}

By the late sixteenth century, current events were increasingly likely to be reported in print, in the form of pamphlets and treatises inspired by particular events. This set up a potential tension with the other event-focused form of factual writing popular with early modern readers, History. As Daniel Woolf has noted, history deals with events that have finished and can be reflected upon, where news combines observation of the past with meditation upon potential futures. ${ }^{75}$ Woolf argued that the news of the later seventeenth century stepped back from the perceived overlap between early printed news and traditional history, leading to a more distinct understanding of the present. The sense of being active within a longer history is certainly very noticeable in news works of the late sixteenth and early seventeenth centuries. At the same time, the content and format of these earlier pamphlets, particularly those dealing with international events, demonstrate that more was at stake than a simple transition from history to current affairs within the public consumption of information, and that was bound up with understandings of time that went beyond past, present and future.

The items examined here show that considerations of time were everpresent in early modern news pamphlets. Indeed, it worked on different levels, often within the same pamphlet, thus reflecting the complicated relationship early modern people had with time. It had considerable value when establishing the pertinent details of a given story, given the frequency with which timerelated particulars appeared prominently on title pages. Time could be used both directly and implicitly to give a sense of narrative within a story; it could also be integral to the story itself, the passage of time within an account contributing directly to its relevance to the reading public, and it could be and often was linked to ongoing considerations about the likelihood that the readers, as well as the protagonists of news, were living at the end of days. News producers had a difficult balance to strike between scaring their readers into an interest in any given story, thus spurring them to buy the news pamphlet, and reassuring them about the veracity of the claims made in their pamphlets, equally important for making a sale. Exploiting the various confusions over time, the quasi-scientific precision of clock-time which was included wherever possible, and the even more pronounced implications of the calendar change fitted neatly with this agenda. A number of news producers of the period were willing to tap into these concerns in order to promote their wares, layering this with a visible presentation of more tangible, one might say more quotidian, 
expressions of time in the form of dates and numbers, conforming with the stylistic and formatting conventions of print in general.

Early modern society was based around ideas of order and stability, and change was almost exclusively understood as being something to be suspected and feared. News was therefore a potentially dangerous genre, as it was an ongoing catalogue of change over time. It brought discord and fear into people's lives, recording the events of the very recent past which had caused and were still causing the tectonic plates of society to shift, without offering an end. Even when readers were assured that the events discussed showed that God was on their side and their cause would eventually be victorious, the very fact that the disturbing events were being recounted in the first place must have been disconcerting to early modern readers, and these final few examples show that these fears were being used to urge readers to change their ways. The same kind of tension between present suffering and eventual reward is seen in Protestant martyrologies, where the godly deaths of co-religionists were not mourned but celebrated, as proof that God supported the church, and was testing it to find it worthy. ${ }^{76}$ From military accounts to monstrous birth pamphlets, the ultimate backdrop to international news around the turn of the century was the possibility that readers were witnessing the End of Days. This was not so much a case of events mattering because the End of Days was considered to be nigh, but the day to day events demonstrating the imminence of the End of Days. The event narrative mattered because it gave a level of precision and clarity to the coming Apocalypse. In this context, news and news print in particular was unsettlingly 'still in progress', an unstable state made all the more obvious by the various techniques producers used to highlight the current validity of their material.

76 S.K. Barker, Protestantism, Poetry and Protest: The Vernacular Writings of Antoine de Chandieu (c.1534-1591) (Farnham: Ashgate, 2009), pp. 161-85. Brad S. Gregory, Salvation at Stake: Christian Martyrdom in Early Modern Europe (Cambridge, MA: Harvard University Press, 1999), esp. pp. 139-96. 